\title{
Nitrogen and Sulfur Concentrations and Flow Rates of Corn Wet-Milling Streams
}

\author{
Kent D. Rausch, ${ }^{1,2}$ Lutgarde M. Raskin, ${ }^{3}$ Ronald L. Belyea, ${ }^{4}$ Thomas E. Clevenger, ${ }^{5}$ and M. E. Tumbleson ${ }^{6}$
}

Nitrogen $(\mathrm{N})$ and sulfur $(\mathrm{S})$ concentrations can affect the market value of coproducts from corn wet-milling. The composition of parent streams would be expected to affect composition of the resulting coproducts but there are few published data available to examine this relationship. Concentration and flow data are needed to determine which streams are important in modifying $\mathrm{N}$ and $\mathrm{S}$ coproduct concentrations. The objective was to measure concentrations and flows of $\mathrm{N}$ and $\mathrm{S}$ in corn wet-milling streams. Samples were taken from 21 process streams from 3 wet-milling plants during two periods of three weeks each; $\mathrm{N}$ and $\mathrm{S}$ concentrations of each sample were determined. There were large differences in $\mathrm{N}$ and $\mathrm{S}$ concentrations among processing streams; within most streams, $\mathrm{N}$ and $\mathrm{S}$ concentrations were similar among plants. Concentrations of $\mathrm{N}$ and $\mathrm{S}$ were related inversely to flow rates. Steepwater and gluten streams contained most of the $\mathrm{N}$ and $\mathrm{S}$ flow and provide an opportunity for modification. The process water stream carried large quantities of $\mathrm{N}$ and $\mathrm{S}$ and represents another opportunity for improving process efficiency and coproduct value.
Wet-milling uses a significant portion of the U.S. corn crop and it is an important agricultural industry resulting in a variety of marketable products and coproducts such as corn starch, high fructose syrup, oil, and germ. In 2005 , the wet-milling industry used $\approx 48$ million tonnes (1.9 billion bushels) of corn or $16 \%$ of the total U.S. corn crop of 300 million tonnes (11.8 billion bushels) (CRA 2006). In wet-milling, the corn kernel is fractionated into components of starch, protein, fiber, and oil. While starch is the primary product in corn wet-milling, two major coproducts are generated: corn gluten meal (CGM) and corn gluten feed (CGF). CGM is produced by dewatering the gluten processing stream; it is characterized by high protein and is used in nonruminant diets. CGF results from the blending of corn fiber and steepwater; it contains high fiber and is used primarily in ruminant diets.

The marketing of corn wet-milling coproducts is economically important because it generates income to offset processing costs. Factors that have the potential to affect quality have a direct impact on the marketing of CGM and CGF. For CGF, variation in protein content is an important marketing issue because protein is biologically important as well as being a costly nutrient. For both CGM and CGF, high sulfur (S) concentration (relative to animal requirements) is an issue because high $\mathrm{S}$ concentrations can lead to adverse physiological problems under certain dietary conditions (NRC 1989). We recently measured the phosphorus (P) concentrations of corn wet-milling processing streams and showed that three streams (light gluten, light steepwater, and process water) accounted for much of the $\mathrm{P}$ flow through the processing plant (Rausch et al 2005). Similar data for protein (measured as $\mathrm{N} \times$ 6.25) are needed due to its economic importance for coproduct value. Nutrient flow data could help identify which streams are the most important carriers of nitrogen $(\mathrm{N})$ and $\mathrm{S}$ and could lead to potential modifications to improve quality of CGF and CGM. However, published data on the flows of nutrients (nitrogen, sulfur,

${ }^{1}$ Associate professor, Agricultural and Biological Engineering, University of Illinois at Urbana-Champaign, 1304 W. Pennsylvania Ave., Urbana, IL 61801.

${ }^{2}$ Corresponding author. Phone: 217-265-0697. Fax: 217-244-0323. E-mail: krausch@ uiuc.edu

${ }^{3}$ Professor, Civil and Environmental Engineering, University of Michigan, 1351 Beal Ave., Ann Arbor, MI 48109.

${ }^{4}$ Professor, Animal Science, University of Missouri, 115 Animal Sciences Center, 920 E. Campus Dr., Columbia, MO 65211.

${ }^{5}$ Professor, Civil Engineering, University of Missouri, E1511 Engineering Building East, Columbia, MO 65211.

${ }^{6}$ Professor emeritus, Agricultural and Biological Engineering, University of Illinois at Urbana-Champaign, 1304 W. Pennsylvania Ave., Urbana, IL 61801.

doi:10.1094/ CCHEM-84-3-0260

C) 2007 AACC International, Inc. and others) in the wet-milling process are difficult to find. The objective was to determine concentrations and flow rates of $\mathrm{N}$ and $\mathrm{S}$ in corn wet-milling streams.

\section{MATERIALS AND METHODS}

Samples were obtained from 21 process streams from three commercial corn wet-milling plants. The streams included corn, process water, process water after sulfur dioxide $\left(\mathrm{SO}_{2}\right)$ addition, light steepwater, heavy steepwater, steepwater condensate, steeped corn, wet germ, wet fiber, pressed germ, pressed fiber, light gluten, heavy gluten, gluten cake, starch slurry, dry germ, CGF, CGM, wastewater, fresh water, and final effluent (Fig. 1). Corn was sampled as it entered steep tanks. Samples of process water and process water with $\mathrm{SO}_{2}$ were taken before and after addition of $\mathrm{SO}_{2}$ and before addition to steep tanks. Light steepwater was obtained from sample ports on lines leading from the steep tanks; heavy steepwater and steepwater condensate were obtained from ports leading from evaporators used to concentrate steepwater. Steeped corn samples were obtained from sample points located near the inlets to the first grind mills. Wet germ and wet fiber were taken from dewatering screens before pressing of germ and fiber. Pressed germ and pressed fiber samples were obtained from respective sampling ports located near the outlets of the dewatering presses. Light gluten and heavy gluten were sampled near gluten-thickener centrifuges; gluten cake was sampled directly from vacuum belt filters. Starch slurry samples were taken downstream from the starch washing hydrocyclones. Dried germ, CGF, and CGM were sampled at ports located near the outlets of the respective drying operations. The wastewater sample was untreated raw waste sampled at a port before the waste treatment system.

Samples were taken during two sampling periods for all three plants. During each sampling period, three sets $(n=21$ each) of samples were obtained. Each sample set was taken during a sevenday period; samples were taken only when operating conditions in the wet-milling plant were considered to be stable. As soon as samples were obtained from process lines, they were placed in sealed containers, frozen, and shipped on dry ice to the University of Illinois for measuring S. Frozen subsamples on dry ice were sent to the University of Missouri for measuring N. Samples were stored frozen until analyzed. Total $\mathrm{S}$ concentrations were measured by standard methods (3.108, AOAC 1984). N was determined by thermal conductivity (Leco 1994). N and S concentration data of streams were analyzed for effects of plant, period, and plant-byperiod interactions using the general linear model (SAS Institute, Cary, NC). Means were separated when main effects were significant $(P<0.05)$ using the least squares means procedure. 


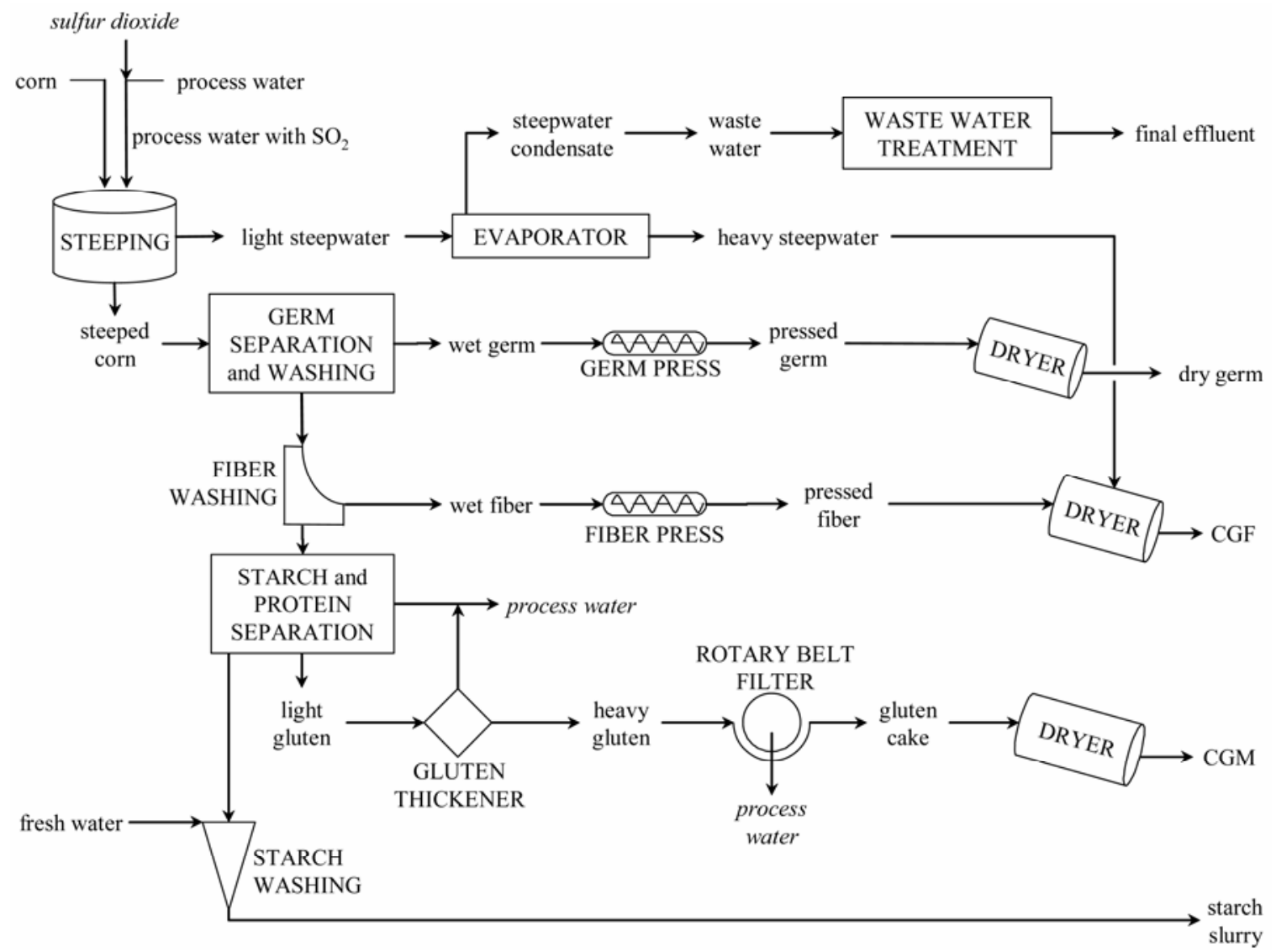

Fig. 1. A simplified corn wet-milling process showing sample locations (CGF, corn gluten feed; CGM, corn gluten meal). Process streams in italics were not sampled.

Flow rates of process streams (kg/day) were estimated for a wetmilling plant with a nominal capacity of 2,700 tonnes/day $(105,000$ bushels/day) using values found in the literature (Blanchard 1999) and a simulation model developed with SuperPro Designer software (v.4.5, Intelligen, Scotch Plains, NJ) by University of Illinois and the Eastern Regional Research Center (USDA-ARS, Wyndmoor, PA). For this simulation, all process flows were assumed to be constant. Wastewater and final effluent flow rates were assumed to be equal to the steepwater condensate flow rates (Fig. 1). This simplified the process of estimating the amount of waste water discharged, but it did not include certain streams because of difficulty in sampling and measurement. Using the total flow rates of process streams and final coproducts from the simulation model, $\mathrm{N}$ and $\mathrm{S}$ flows for each plant were estimated from the model using the respective concentrations of streams for each plant.

\section{RESULTS AND DISCUSSION}

There were few significant period or period-by-processing plant effects on $\mathrm{N}$ and $\mathrm{S}$ concentrations of streams, therefore discussion will be focused only on effects of processing plants. $\mathrm{N}$ concentrations varied among processing streams (Table I). Some streams (starch slurry, fresh water) had low $\mathrm{N}$ concentrations $(<1,000 \mathrm{mg} / \mathrm{kg})$. Several streams (CGM, corn gluten cake, CGF, heavy gluten) had high $(>10,000 \mathrm{mg} / \mathrm{kg}) \mathrm{N}$ concentrations. For more than half of the processing streams (12 of 21$)$, there were no differences in $\mathrm{N}$ concentrations among plants. However, for several streams, there were differences among plants $(P<0.05$, Table I). N content of corn gluten feed was higher for plants $\mathrm{B}$ and $\mathrm{C}$ than for plant $\mathrm{A}$; the $\mathrm{N}$ content of heavy steepwater was greater for plants A and B than for plant $\mathrm{C}$. $\mathrm{N}$ content of wet germ from plant $\mathrm{B}$ was higher than wet germ from plants $\mathrm{A}$ and $\mathrm{C}$. The
TABLE I

Nitrogen Concentrations (mg/kg of sample) of Corn Wet-Milling Streams ${ }^{\mathrm{a}, \mathrm{b}}$

\begin{tabular}{lcccc}
\hline Sampling Point & Plant A & Plant B & Plant C & SE$^{\mathbf{c}}$ \\
\hline Corn & 10,960 & 7,450 & 11,500 & 1,262 \\
Process water & 1,180 & - & 2,127 & 235 \\
Process water with $\mathrm{SO}_{2}$ & 1,078 & - & 3,943 & 518 \\
Steeped corn & 9,385 & 13,100 & 9,327 & 1,318 \\
Light steepwater & 5,390 & - & 7,935 & 587 \\
Heavy steepwater & $30,110 \mathrm{a}$ & $33,920 \mathrm{a}$ & $27,220 \mathrm{~b}$ & 1,275 \\
Steepwater condensate & $0.40 \mathrm{a}$ & $1.57 \mathrm{~b}$ & $0.60 \mathrm{a}$ & 0.23 \\
Wet germ & $11,760 \mathrm{a}$ & $22,710 \mathrm{~b}$ & $15,680 \mathrm{a}$ & 2,253 \\
Pressed germ & 17,850 & 18,860 & 16,630 & 1,800 \\
Dry germ & $16,600 \mathrm{a}$ & $16,800 \mathrm{a}$ & $21,330 \mathrm{~b}$ & 672 \\
Wet fiber & 15,830 & 10,270 & 25,700 & 5,157 \\
Pressed fiber & $1,517 \mathrm{a}$ & $11,840 \mathrm{~b}$ & $19,660 \mathrm{c}$ & 1,490 \\
Corn gluten feed & $12,330 \mathrm{a}$ & $32,670 \mathrm{~b}$ & $31,530 \mathrm{~b}$ & 1,277 \\
Light gluten & 4,430 & - & 4,303 & 967 \\
Heavy gluten & 14,820 & 23,183 & 35,917 & 18,482 \\
Gluten cake & 80,490 & 82,180 & 76,180 & 2,287 \\
Corn gluten meal & 102,070 & 99,310 & 99,280 & 3,335 \\
Starch slurry & 450 & - & 1,958 & 790 \\
Fresh water & $5.6 \mathrm{a}$ & $4.7 \mathrm{a}$ & $1.2 \mathrm{~b}$ & 0.84 \\
Waste water & $1.1 \mathrm{a}$ & $5.0 \mathrm{~b}$ & $0.8 \mathrm{a}$ & 0.5 \\
Final effluent & - & - & 250 & - \\
\hline
\end{tabular}

${ }^{a}$ Mean values with the same letters within the same row are not significantly different at $P<0.05$.

b Values with no letters are not different at $P<0.05$.

${ }^{c}$ Standard error of the mean.

$\mathrm{N}$ content of pressed fiber was lower for plant A than for plants B and $\mathrm{C}$. This could be attributed to operating differences among plants. Differences (nearly an order of magnitude) were greater than differences among plants for other streams. The reasons for these differences were not apparent. 
The S concentrations also varied among processing streams (Table II). Several streams (i.e., steepwater condensate, fresh water, waste water) had low ( $<100 \mathrm{mg} / \mathrm{kg}) \mathrm{S}$ concentrations; other streams (CGM, CGF, heavy steepwater) had high $(>3,000 \mathrm{mg} / \mathrm{kg}) \mathrm{S}$ concentrations. For many streams (11 of 21$)$, there were no differences in $\mathrm{S}$ concentrations among processing plants. For some streams, however, there were differences among plants. The S concentrations of heavy steepwater from plants A and B were greater than for plant $\mathrm{C}$, while plant $\mathrm{A}$ had lower $\mathrm{S}$ concentrations in pressed fiber than in pressed fiber from plants B and C. CGF is produced by the blending of pressed fiber and heavy steepwater. Although there were differences among plants in $\mathrm{S}$ concentration of the two parent streams (pressed fiber and heavy steepwater), the $\mathrm{S}$ concentration of CGF did not differ among plants. For both

TABLE II

Sulfur Concentrations $(\mathrm{mg} / \mathrm{kg})$ of Corn Wet-Milling Streams ${ }^{\mathrm{a}}$

\begin{tabular}{lcccc}
\hline Sampling Point & Plant A & Plant B & Plant C & SE $^{\mathbf{b}}$ \\
\hline Corn & 855 & 802 & 853 & 97 \\
Process water & 326 & 317 & 370 & 61 \\
Process water with $\mathrm{SO}_{2}$ & 1,133 & 927 & 747 & 472 \\
Steeped corn & 936 & 995 & 793 & 96 \\
Light steepwater & 612 & 317 & 580 & 225 \\
Heavy steepwater & $3,180 \mathrm{a}$ & $3,770 \mathrm{~b}$ & $2,350 \mathrm{c}$ & 136 \\
Steepwater condensate & $15.0 \mathrm{a}$ & $3.4 \mathrm{~b}$ & $3.2 \mathrm{~b}$ & 1.5 \\
Wet germ & $590 \mathrm{a}$ & $1,033 \mathrm{~b}$ & $775 \mathrm{a}$ & 107 \\
Pressed germ & $1,833 \mathrm{a}$ & $1,555 \mathrm{ab}$ & $1,203 \mathrm{~b}$ & 270 \\
Dry germ & $2,500 \mathrm{a}$ & $3,800 \mathrm{~b}$ & $3,167 \mathrm{~b}$ & 287 \\
Wet fiber & 988 & 318 & 608 & 279 \\
Pressed fiber & $787 \mathrm{a}$ & $1,133 \mathrm{~b}$ & $1,291 \mathrm{~b}$ & 115 \\
Corn gluten feed & 3,620 & 3,365 & 3,483 & 1,606 \\
Light gluten & 490 & 333 & 430 & 208 \\
Heavy gluten & 1,816 & 1,850 & 2,017 & 161 \\
Gluten cake & 4,033 & 4,350 & 4,467 & 343 \\
Corn gluten meal & 9,683 & 10,330 & 10,670 & 525 \\
Starch slurry & $154.2 \mathrm{a}$ & $74.9 \mathrm{~b}$ & $9.7 \mathrm{c}$ & 18.0 \\
Fresh water & $36.9 \mathrm{a}$ & $234.3 \mathrm{~b}$ & $406.7 \mathrm{~b}$ & 66.7 \\
Waste water & $20.5 \mathrm{a}$ & $89.3 \mathrm{~b}$ & $4.8 \mathrm{c}$ & 2.2 \\
Final effluent & $25.7 \mathrm{a}$ & $77.5 \mathrm{~b}$ & $98.3 \mathrm{c}$ & 6.3 \\
\hline a & & & &
\end{tabular}

${ }^{a}$ Mean values with the same letters within the same row are not significantly different at $(P<0.05)$.

${ }^{\mathrm{b}}$ Standard error of the mean.
$\mathrm{N}$ and $\mathrm{S}$ concentration data, values are expressed on a wet (as is) basis.

$\mathrm{N}$ and $\mathrm{S}$ concentrations provide relative comparisons of processing streams but do not indicate absolute quantities of nutrient flow. When flow rates of streams and concentration data are available, the quantities of $\mathrm{N}$ or $\mathrm{S}$ carried in a stream (flow data) can be estimated as flow rate $\times$ concentration. Flow data are useful because they provide estimates of absolute quantities carried in process streams. Flow data can be used to indicate the importance of each stream in the $\mathrm{N}$ and $\mathrm{S}$ balances of processing plants and can be used to identify important control points for potential manipulation of process streams. Recently, we reported a study in which $\mathrm{P}$ concentrations of streams and flow rate data were used to estimate the flows (quantities) of $\mathrm{P}$ in different corn wet-milling streams (Rausch et al 2005). P concentrations related inversely to flow rates; two streams were responsible for carrying most of the $\mathrm{P}$. In this study, flow rates for $\mathrm{N}$ and $\mathrm{S}$ were estimated using the same modeling approach in Rausch et al (2005) (Table III). As was true for $\mathrm{P}$ flow, nutrient ( $\mathrm{N}$ and $\mathrm{S}$ ) concentrations were related inversely to nutrient flow; for example, dry germ and heavy gluten had similar $\mathrm{N}$ concentrations $(18,911$ and $21,961 \mathrm{mg}$ of $\mathrm{N} / \mathrm{kg}$, respectively). Yet nutrient flows $(3,904$ and $30,212 \mathrm{~kg}$ of $\mathrm{N} /$ day) were much different. These differences apparently reflect differences in flow rates of streams.

Based on concentrations and simulated flow rates, total $\mathrm{N}$ entering the wet-milling process was $26,845 \mathrm{~kg}$ of N/day (Table III, Fig. 2). Total amount of $\mathrm{N}$ leaving the process in coproducts and various waste streams was estimated to be $42,455 \mathrm{~kg}$ of N/day. Amounts of $\mathrm{N}$ carried by the different processing streams varied. Some streams ( 7 of 21 ) carried relatively small quantities of $\mathrm{N}$ $(<5,000 \mathrm{~kg}$ of $\mathrm{N} /$ day $)$. Of the remaining streams, four carried 5,000 to $10,000 \mathrm{~kg}$ of $\mathrm{N} /$ day and 10 streams carried $\geq 10,000 \mathrm{~kg}$ of $\mathrm{N} /$ day. Likewise, $\mathrm{S}$ concentrations of different processing streams also varied. The amount of S entering the wet-milling process was estimated to be $4,762 \mathrm{~kg}$ of S/day, which included $2,370 \mathrm{~kg}$ of $\mathrm{S} /$ day originating from corn and $1,773 \mathrm{~kg}$ of $\mathrm{S} /$ day added as $\mathrm{SO}_{2}$ (Fig. 2; Table IV); total $\mathrm{S}$ leaving in coproduct and other streams was estimated to be $5,010 \mathrm{~kg}$ of S/day. The difference between input and output $\mathrm{S}, \approx 248 \mathrm{~kg}$ of $\mathrm{S} /$ day (5.2\% of $\mathrm{S}$ input), can be attributed to addition of $S$ to control microbial growth in process tanks before dewatering and drying. Some loss of $\mathrm{S}$ was anticipated

TABLE III

Nitrogen and Sulfur Concentrations ${ }^{\mathrm{a}}$ and Flow Rates ${ }^{\mathrm{b}}$ in Corn Wet-Milling

\begin{tabular}{|c|c|c|c|c|c|}
\hline Sampling Point & $\begin{array}{c}\text { Total Flow } \\
\left(\times 10^{3} \mathrm{~kg} / \mathrm{day}\right)\end{array}$ & $\begin{array}{l}\text { Nitrogen Conc. } \\
\text { (mg/kg sample) }\end{array}$ & $\begin{array}{l}\text { Nitrogen Flow } \\
\text { (kg of N/day) }\end{array}$ & $\begin{array}{c}\text { Sulfur Conc. } \\
\text { (mg/kg of sample) }\end{array}$ & $\begin{array}{c}\text { Sulfur Flow } \\
\text { (kg of S/day) }\end{array}$ \\
\hline Corn & 2,727 & 9,839 & 26,832 & 869 & 2,370 \\
\hline Process water & 2,960 & 1,653 & 4,894 & 338 & 1,000 \\
\hline Process water with $\mathrm{SO}_{2}$ & 2,964 & 2,511 & 7,443 & 936 & 2,773 \\
\hline Steeped corn & 4,223 & 10,088 & 42,599 & 836 & 3,528 \\
\hline Light steepwater & 1,403 & 6,663 & 9,344 & 520 & 729 \\
\hline Heavy steepwater & 332 & 30,422 & 10,108 & 3,152 & 1,047 \\
\hline Steepwater condensate & 1,070 & 0.656 & 1 & 7.0 & 7 \\
\hline Wet germ & 1,324 & 14,073 & 18,639 & 669 & 887 \\
\hline Pressed germ & 345 & 15,923 & 5,490 & 1,376 & 474 \\
\hline Dry germ & 206 & 18,911 & 3,904 & 2,867 & 592 \\
\hline Wet fiber & 3,468 & 14,626 & 50,722 & 678 & 2,350 \\
\hline Pressed fiber & 606 & 10,900 & 6,604 & 1,015 & 615 \\
\hline Corn gluten feed & 448 & 25,467 & 11,408 & 3,823 & 1,713 \\
\hline Light gluten & 5,229 & 4,367 & 22,833 & 418 & 2,185 \\
\hline Heavy gluten & 1,376 & 21,961 & 30,212 & 1,822 & 2,507 \\
\hline Gluten cake & 514 & 68,644 & 35,303 & 4,133 & 2,126 \\
\hline Corn gluten meal & 230 & 100,194 & 23,070 & 10,133 & 2,333 \\
\hline Starch slurry & 3,648 & 1,092 & 3,982 & 81.6 & 298 \\
\hline Fresh water & 3,423 & 4 & 13 & 181 & 619 \\
\hline Wastewater & 1,070 & 2.22 & 2 & 38.1 & 41 \\
\hline Final effluent ${ }^{\mathrm{c}}$ & 1,070 & 84.6 & 91 & 69.4 & 74 \\
\hline
\end{tabular}

a Concentrations are means of all samples from three plants.

b Total flow rates estimated using simulation model.

c Material leaving waste treatment facility. 
due to evaporation but it was not measured. For $\mathrm{S}$, the quantities carried in each stream varied in the same manner noted for $\mathrm{N}$ (Table III). Most streams (10 of 21) carried smaller quantities of $S$ $(<1,000 \mathrm{~kg}$ of S/day), while several streams (8 of 21) carried greater quantities of $\mathrm{S}(\geq 2,000 \mathrm{~kg}$ of $\mathrm{S} /$ day).

Corn was responsible for supplying much of the $\mathrm{N}(26,832 \mathrm{~kg}$ of N/day) entering the steeping process (Fig. 3; Table IV). Two streams (steeped corn and light steepwater) left the steeping process (Fig. 1). Total $\mathrm{N}$ found in these two streams $(51,943 \mathrm{~kg}$ of $\mathrm{N} /$ day) exceeded input streams by $\geq 17,000 \mathrm{~kg}$ of $\mathrm{N} /$ day. It is not clear why the estimates for $\mathrm{N}$ entering and exiting the steeping step (or for overall $\mathrm{N}$ input and output discussed earlier) are disparate but it probably reflects errors in sampling process water streams and in estimates of process water flow. For example, it is possible that $\mathrm{N}$ concentrations of process water varied during a sampling period due to fluctuations in separations in other processing steps. This could result in samples being taken during a relative concentration minimum that does not reflect accurately the true $\mathrm{N}$ concentrations of streams over a longer period of time. The two streams leaving the steeping process (steeped corn and light steep water) accounted for $4,257 \mathrm{~kg}$ of S/day (Fig. 3). The most important coproduct streams carrying $S$ were gluten streams $(2,100-$ $2,500 \mathrm{~kg}$ of S/day), wet fiber (2,350 kg of S/day), and heavy steepwater $(1,047 \mathrm{~kg}$ of $\mathrm{S} /$ day $)$. These three streams carried $75 \%$ of total $\mathrm{S}$ flow in the wet-milling process. Low amounts of $\mathrm{S}$ were found in the starch and waste streams $(<300 \mathrm{~kg}$ of S/day).

Two streams that carried large quantities of $\mathrm{N}$ were gluten and steepwater streams. In each case, the quantity of $\mathrm{N}$ carried across different processing steps within each of these streams was relatively consistent. It might be possible to modify these streams to increase $\mathrm{N}$ content by removing inorganics or other nutritionally less valuable components. This could increase the market value of

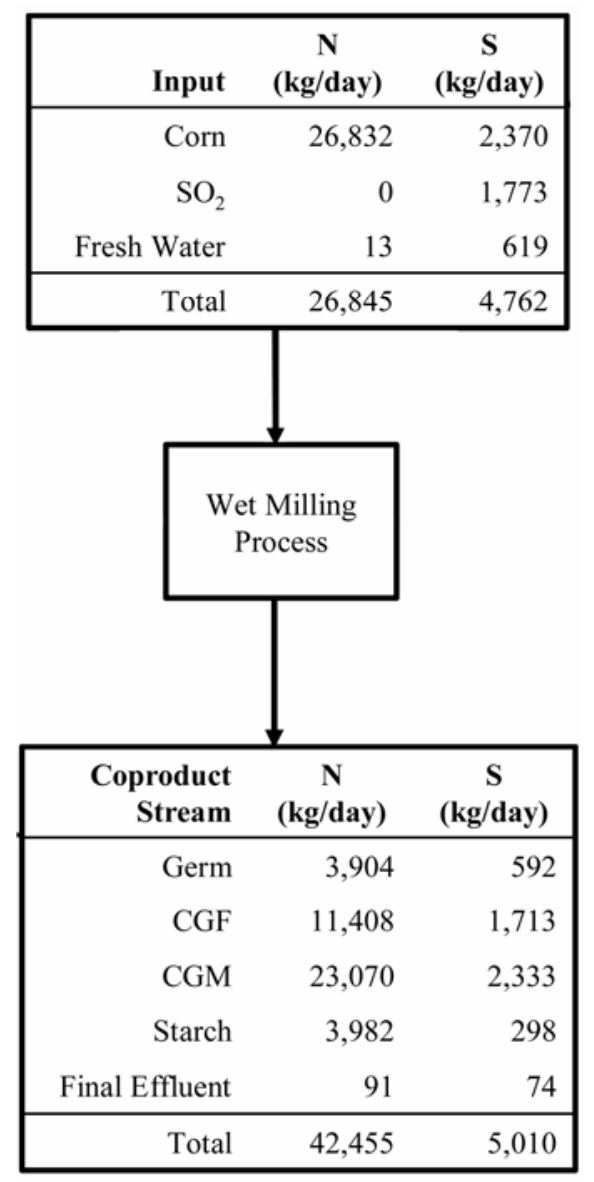

Fig. 2. Overall nitrogen and sulfur flows for the wet-milling process (CGF, corn gluten feed; CGM, corn gluten meal). the resulting material (coproducts) because protein $(\mathrm{N} \times 6.25)$ is a valuable entity. Two other processing streams (wet fiber and wet germ) provide additional potential processing opportunities. In both cases, large quantities $(\approx 30,000 \mathrm{~kg}$ total $)$ of $\mathrm{N}$ were recovered and (presumably) diverted into process water. If process water streams were processed further, using microfiltration or other technologies for example, recovered $\mathrm{N}$ (protein) could form a concentrated protein stream of potentially high market value or could be added to existing streams. An additional benefit may be that the resulting process water would be cleaner and more effective as it is recycled through the wet-milling process. One could make the same argument for removing S from process water; high S concentrations in coproducts are not necessary and could be detrimental in some dietary situations.

Flows and recoveries of nutrients in corn wet-milling streams are difficult to measure or estimate. Concentrations of nutrients in processing streams can vary substantially during any sampling period, making it difficult to obtain representative samples. In addition, flow rates are difficult to estimate due to inherent process fluctuations and differences in actual flow rates among plants. The process simulation is not able to take into account the process fluctuations that will inevitably occur in a commercial setting. This becomes apparent when one compares nutrient flows for $\mathrm{N}$ and $\mathrm{S}$ from this study and $\mathrm{P}$ from our previous work (Rausch et al 2005; Table IV). For P and N, the nutrient quantities accounted

TABLE IV

Comparison of Flows of Nitrogen, Sulfur, and Phosphorus in Corn Wet-Milling Streams (kg of nutrient/day)

\begin{tabular}{lrrr}
\hline Process Stream & $\mathbf{P a}^{\mathbf{a}}$ & $\mathbf{N}$ & $\mathbf{S}$ \\
\hline Input & & & \\
$\quad$ Corn & 5,900 & 26,832 & 2,370 \\
Fresh water & 17 & 13 & 619 \\
SO $_{2}$ addition & 0 & 0 & 1,773 \\
$\quad$ Total & 5,917 & 26,845 & 4,762 \\
Leaving steep tank & & & \\
$\quad$ Steepwater & 3,160 & 9,344 & 729 \\
$\quad$ Steeped corn & 5,690 & 42,599 & 3,528 \\
$\quad$ Total & 8,850 & 51,943 & 4,257 \\
Leaving in coproducts & & & \\
$\quad$ and other streams & 3,920 & 42,455 & 5,010 \\
\hline
\end{tabular}

${ }^{a}$ Rausch et al (2005).

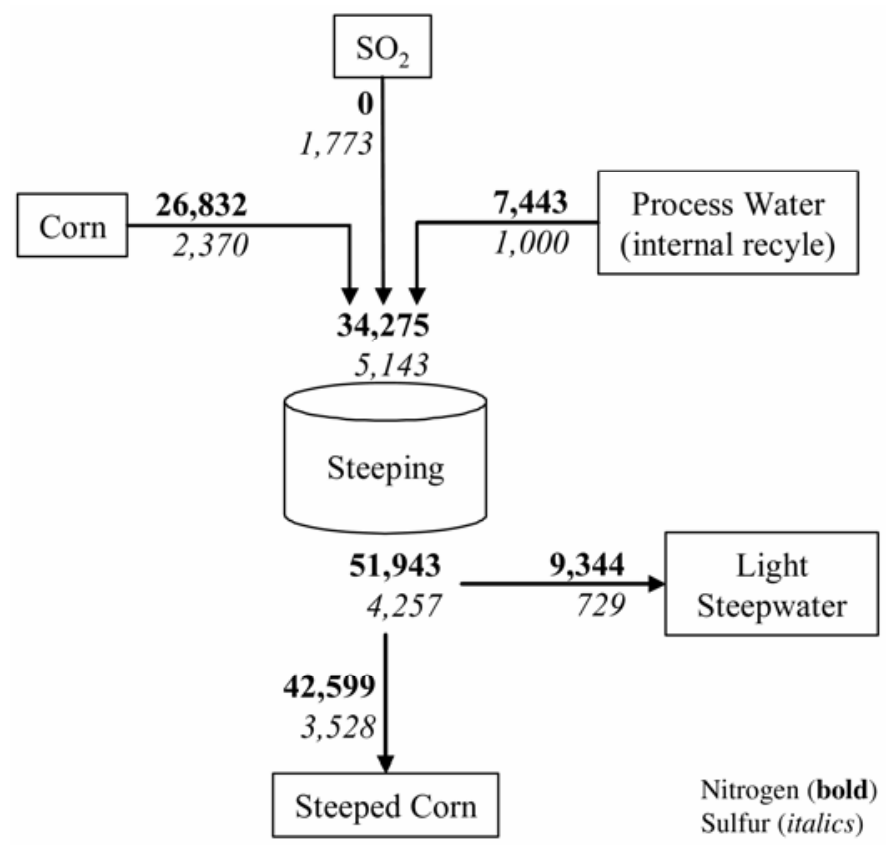

Fig. 3. Flows (kg/day) of nitrogen and sulfur in the steeping process. 
for in the input streams were 70 and $50 \%$, respectively, of that leaving the steeping process; whereas for $\mathrm{S}$, the input streams exceeded the quantity leaving the steeping process. For $\mathrm{P}$ and $\mathrm{N}$, the quantities of nutrients leaving the steep tank exceeded those found in coproduct and other streams; whereas for S it was less. Considerable amounts of nutrients are recycled in process water and accounting for process water input is difficult. Thus, lack of accurate accounting of nutrient flow is not surprising. Additional study would be needed to increase the precision of the nutrient accounting and to identify potential opportunities for improving process efficiency and coproduct quality.

\section{CONCLUSIONS}

There were large differences in $\mathrm{N}$ and $\mathrm{S}$ concentrations among processing streams from corn wet-milling plants; within streams, processing plants did not vary. Nutrient concentrations of streams and nutrient flow were related inversely. Several streams were responsible for carrying most of the $\mathrm{N}$ and $\mathrm{S}$; these included steepwater and gluten streams; additional processing of these streams could improve coproduct quality. Processing of recycled water from the germ press and fiber press also could improve processing efficiency and coproduct market value.

\section{ACKNOWLEDGMENTS}

Funded in part by the Waste Management Research Center, Champaign, IL (DNR Contract No. HWR01168). We acknowledge the assistance of the Illinois State Geological Survey, Champaign, IL, and the Urbana Champaign Sanitary District, Urbana, IL.

\section{LITERATURE CITED}

AOAC. 1984. Official Methods of Analysis, 14th Ed. Method 3.108. AOAC International: Gaithersburg MD.

Blanchard, P. H. 1999. Technology of Corn Wet Milling and Associated Processes, 2nd Ed. Elsevier Press: Amsterdam.

CRA. 2006. Corn: Part of a Sustainable Environment. Corn Annual. Corn Refiners Assoc.: Washington, DC.

NRC. 1989. Nutrient Requirements of Dairy Cattle, 6th Ed. Natl. Res. Council, National Academy of Science: Washington, DC.

Rausch, K. D., Raskin, L. M., Belyea, R. L., Agbisit, R. M., Daugherty, B. J., Clevenger, T. E., and Tumbleson, M. E. 2005. Phosphorus concentrations and flow in maize wet-milling streams. Cereal Chem. 82:431-435.

[Received May 10, 2006. Accepted January 29, 2007.] 